\title{
Uwarunkowania geograficzne i historyczne ksztaltowania krajobrazu kulturowego na obszarze województwa podkarpackiego
}

\begin{abstract}
W artykule dokonano uzasadnienia powiązania uwarunkowań geograficznych i historycznych kwestią kształtowania krajobrazu kulturowego. W tym celu przeprowadzono analizę czynników przyrodniczych i historycznych na obszarze województwa podkarpackiego na tle jego obecnych granic. Obszar województwa podkarpackiego posiada niezaprzeczalne walory kulturowe, które powstały na przestrzeni wieków pod znacznym wpływem trzech głównych kultur: polskiej, ukraińsko-ruskiej i żydowskiej. O atrakcyjności tego regionu decyduje więc zarówno wielokulturowy charakter zachowanych obiektów zabytkowych, jak i ich ogromna liczba. Głównym celem badawczym artykułu było rozpoznanie i zdefiniowanie uwarunkowań geograficznych i historycznych, które wpłynęły na zmiany zachodzące na przestrzeni wieków w krajobrazie kulturowym na terenach znajdujących się obecnie w granicach województwa podkarpackiego. Istniejące na obszarze tego województwa obiekty zabytkowe, zarówno świeckie, jak i sakralne, są jedną z atrakcji turystycznych przyciągających turystów. Jednak również w obecnych czasach wiele czynników wpływa na to, że część z tych wielokulturowych obiektów zanika, a krajobraz ulega zasadniczym przekształceniom.
\end{abstract}

Słowa kluczowe: krajobraz kulturowy, wielokulturowość, zabytki, cerkiew, synagoga.

\section{Wstęp}

Krajobraz kulturowy to jeden z najważniejszych i zarazem najstarszych przedmiotów badań w geografii. Termin ten jest też różnorodnie interpretowany w różnych subdyscyplinach geograficznych. Krajobraz kulturowy, jak twierdziła jedna z wybitnych przedstawicielek geografii polskiej M. Dobrowolska, stanowi syntezę działalności społeczeństwa w jego środowisku geograficznym. Najlepiej odzwierciedla on współzależność między przyrodą a życiem ludzkim, zachodzącą w ciągu długiego rozwoju historycznego (Dobrowolska 1948). Zamysł współzależności i konfiguracji pewnych elementów zbieżny jest z poglądami niemieckich klasy- 
ków geografii, w tym A. Hettnera, który jako pierwszy podał naukową definicję krajobrazu, uznając, że jest on „widzialnym wyrazem faktów i zjawisk, zachodzących na jakiejkolwiek określonej działce powierzchni ziemi" (Hettner 1927). Jednym z głównych założeń było uchwycenie sensu i rezultatów ludzkiej działalności w środowisku przyrodniczym i społecznym. W badaniach nad krajobrazem kulturowym analizuje się m.in. również czasoprzestrzenne konsekwencje działalności człowieka w środowisku, co stwarza możliwość wychwycenia ewolucji historycznej. Jednak dopiero pod koniec XX w. zwrócono uwagę, że ważna jest ochrona krajobrazu zarówno materialnego, jak i niematerialnego jako całości. Do tego czasu osobno traktowano ochronę przyrody, którą interesowali się głównie przyrodnicy, ekolodzy oraz geografowie. Natomiast ochroną krajobrazu kulturowego materialnego zajmowali się nieliczni przedstawiciele dziedzin związanych z dziedzictwem kulturowym (m.in. historycy sztuki, architekci krajobrazu, etnografowie, archeolodzy). Zmiany społeczno-gospodarcze, zachodzące w Europie, w tym także w Polsce, w XX w. spowodowały znaczne przeobrażenia w strukturze miast, a nawet całych regionów. Postępująca urbanizacja na zawsze zmieniła krajobraz. Chroniono pojedyncze obiekty zabytkowe, nie zwracając niestety uwagi na ich otoczenie i funkcjonowanie w tkance miasta, w wyniku czego przy ruchliwych ulicach stoją teraz zabytkowe dwory i pałace, pozbawione parków i założeń dworskich, niejako wyrwane z dawnych czasów i przeniesione do współczesnych.

Z wymienionych powyżej powodów na początku XXI w. Rada Europy opracowała i wdrożyła dokument mający na celu ochronę krajobrazów naturalnych i kulturowych oraz organizowanie europejskiej współpracy w tym zakresie. W 2000 r. uchwalono Europejską Konwencję Krajobrazową, której głównym celem jest sprawienie, by w poszczególnych państwach Unii Europejskiej powstał system prawny, pozwalający sprawnie zarządzać procesem kształtowania i ochrony krajobrazu. Działania te mają doprowadzić m.in. do osiągnięcia równowagi pomiędzy procesami rozwojowymi a wymogami zachowania wartościowych elementów środowiska i udostępnianiem najcenniejszych walorów krajobrazowych społeczeństwu.

Działania Komitetu Światowego Dziedzictwa UNESCO także podkreślają znaczenie ochrony krajobrazu kulturowego. Pod koniec XX w. Komitet wprowadził nową kategorię dóbr kultury - jednostkę krajobrazu kulturowego, a następnie zalecił, aby tę kategorię eksponować we wnioskach o wpisy na listę światowego dziedzictwa. Warto podkreślić, że wpisy całych zespołów miejskich mają również na celu zachowanie zabytkowej tkanki, a tym samym krajobrazu architektonicznego danego miasta. W Polsce egzemplifikacją może być Stare Miasto w Krakowie 
(wpisane na listę w 1978 r.), Stare Miasto w Zamościu (wpisane w 1992 r.), czy średniowieczny zespół miejski w Toruniu (wpisany w 1997 r.). Przykładem obszaru uznawanego właśnie za krajobraz kulturowy jest Kalwaria Zebrzydowska. W przyjętym przez UNESCO w 1999 r. na sesji w Marrakeszu uzasadnieniu wpisu znajduje się m.in. fragment, w którym mowa o tym, że Kalwaria:

stanowi wyjątkowy pomnik kultury, w którym krajobraz kulturowy posłużył jako rama symbolicznego przedstawienia Pasji Chrystusa w formie kaplic i alej. Jest to więc krajobraz kulturowy o wielkim pięknie i wielkiej wartości duchowej, w którym elementy natury i stworzone przez człowieka łączą się harmonijnie $[\ldots]^{1}$.

Województwo podkarpackie jest regionem, który posiada bardzo charakterystyczny krajobraz kulturowy. Tworzą go m.in.: zabudowa małomiasteczkowa, świątynie rzymskokatolickie i klasztory, licznie zachowane cerkwie oraz synagogi. Region ten wyróżniał się dotychczas również dużą liczbą drewnianych obiektów, w szczególności cerkwi na terenach górskich i przygranicznych. Związane było to nieodłącznie z faktem, że od wieków ten obszar należał to tzw. biedniejszych. Zarówno domy, jak i świątynie budowano z drewna - z materiału, który był łatwo dostępny, a przy tym tani. Położenie w otoczeniu rozległych puszcz karpackich, które nie tylko dostarczały budulec, ale też stanowiły swoistą izolację od pozostałych obszarów kraju, przyczyniło się do tego, że do czasów teraźniejszych na tym terenie przetrwała znaczna liczba drewnianych obiektów. Na zachodzie Europy i w Polsce drewniana architektura została wcześnie zastąpiona budowlami kamiennymi i murowanymi. Przykładem może być Śląsk, na którym już pod koniec XII w. nie było drewnianych kościołów. Wiele innych czynników historycznych, geograficznych i społecznych wpłynęło także na to, że Podkarpacie wyróżnia się na mapie naszego kraju charakterystycznym krajobrazem kulturowym. Jednak pomimo przygranicznego położenia, w oddali od głównych ośrodków miejskich i gospodarczych, również ten region rozwija się w ostatnich latach. Niestety w ślad za tym idą niekorzystne zmiany. Zanika drewniana zabudowa miast i wsi, drewniane świątynie zostają zastąpione przez większe, murowane. Jest to nieodłączny element tzw. bogacenia się społeczeństw. Drewno, uznawane za materiał używany przez ludzi biednych, wypierane jest przez kamień, świadczący o zamożności mieszkańców. Bezpowrotnie zmienia się także krajobraz wsi. Zanikają drewniane zabudowania otoczone płotem i ogrodem. Zastępują je okazałe „dwory” i ,pałace”, które z zabudową wiejską, czy też regionalną nie mają

${ }^{1} \mathrm{http} / /$ kalwaria.eu/strona/kalwaria-zebrzydowska-swiatowym-dziedzictwem-kultury (7.09.2017). 
żadnego związku. W wielu przypadkach taki los spotyka także zabytkowe świątynie, które stoją opuszczone i niszczeją w cieniu nowo wybudowanych, murowanych.

\section{Ogólna charakterystyka obszaru i przedmiotu badań}

Województwo podkarpackie położone jest w południowo-wschodniej części Polski. Według podziału na regiony fizycznogeograficzne Polski autorstwa J. Kondrackiego (2009) teren województwa położony jest w obrębie regionu Karpaty i Podkarpacie oraz w południowo-wschodniej części regionu Wyżyna Lubelsko-Lwowska (ryc. 1). Na terenie Polski, w tym województwa podkarpackiego, znalazły się tylko dwie prowincje regionu Karpat i Podkarpacia: zachodniokarpacka i w małym stopniu wschodniokarpacka. Wspomniana prowincja wschodniokarpacka zajmuje małą część na obszarze Polski. Stanowi ona makroregion Podkarpacia Wschodniego o powierzchni $100 \mathrm{~km}^{2}$, znajdujący się na południe od Przemyśla, w dorzeczu Wiaru (Kondracki 2009).

Przedmiotem badań autorki niniejszego tekstu były wybrane grupy sakralnych obiektów zabytkowych, zlokalizowanych na terenie województwa podkarpackiego, które zostały wpisane do rejestru zabytków nieruchomych w Narodowym Instytucie Dziedzictwa (na podstawie danych z 4.04.2016 r.). To właśnie zachowane obiekty sakralne w najlepszy sposób odzwierciedlają wielokulturowość regionu, a trwając w łączności z otoczeniem, tworzą jego krajobraz kulturowy.

Na potrzeby artykułu wybrano obiekty sakralne, reprezentujące religie i kultury występujące na badanym terenie (poza świątyniami rzymskokatolickimi). Budynki te pogrupowano na:

- cerkwie, zespoły cerkiewne;

- synagogi, bożnice.

Przestrzenne rozmieszczenie zabytków na obszarze Polski pozwala na szczegółową analizę czynników geograficznych i historycznych, które wpłynęły na stan liczebny zachowanych budynków. Największa liczba obiektów zabytkowych ogółem w kraju znajduje się kolejno w województwach: dolnośląskim, wielkopolskim i mazowieckim. Natomiast najniższą liczbę wykazuje województwo świętokrzyskie, w którym zabytki stanowią 19,7\%. Obiekty te w niewielkiej liczbie zlokalizowane są również w województwach podlaskim i łódzkim.

Przedstawione $\mathrm{w}$ tab. 1 zestawienie potwierdza uwarunkowania historyczne lokalizacji obiektów. Województwa dominujące to obszary o wysokich wskaźnikach gospodarczych, a także znacznych pozycjach strategicznych (obronnych) w poprzednich wiekach. Najzasobniejsze w tym względzie województwo dolno- 
śląskie reprezentują takie miasta, jak Wrocław i Legnica. Jest to część historycznego Śląska. Drugie w zestawieniu jest województwo wielkopolskie, zarazem najstarsza historycznie dzielnica państwa polskiego, kolebka polskiej państwowości. Największymi i najważniejszymi funkcjonalnie miastami były wówczas m.in.: Poznań, Ostrów Lednicki, Kalisz i Gniezno. Kolejne województwo, mazowieckie, pod względem zasobności reprezentowane jest przede wszystkim przez Warszawę, w której znajduje się bardzo duża liczba obiektów zabytkowych. Mazowsze było jedną z najlepiej zorganizowanych i najzasobniejszych dzielnic państwa Piastów. Przebiegały tędy szlaki handlowe do Małopolski i na Ruś.

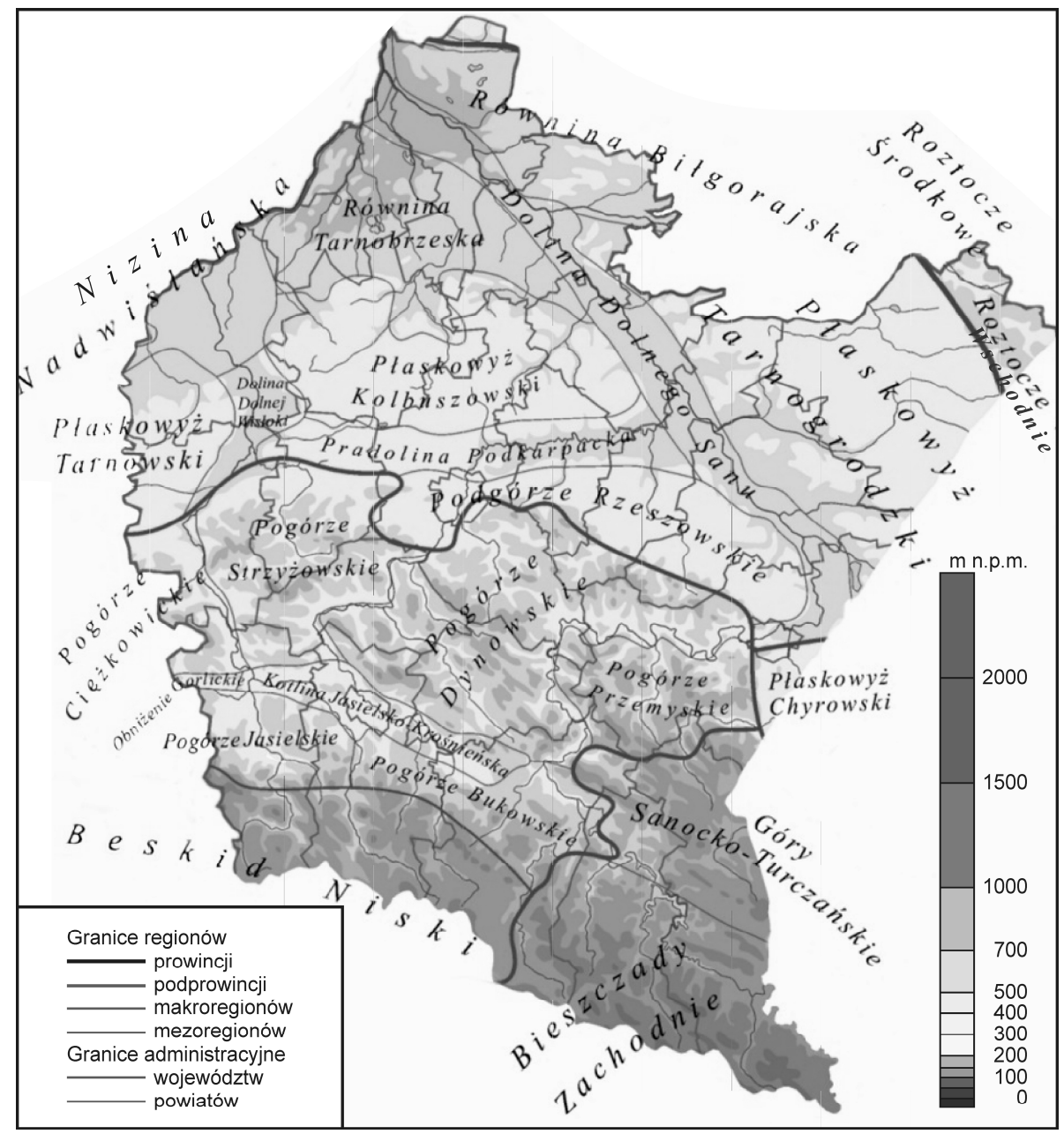

Ryc. 1. Regiony fizycznogeograficzne według J. Kondrackiego (2009) Źródło: opracowanie własne w oparciu o źródła kartograficzne 


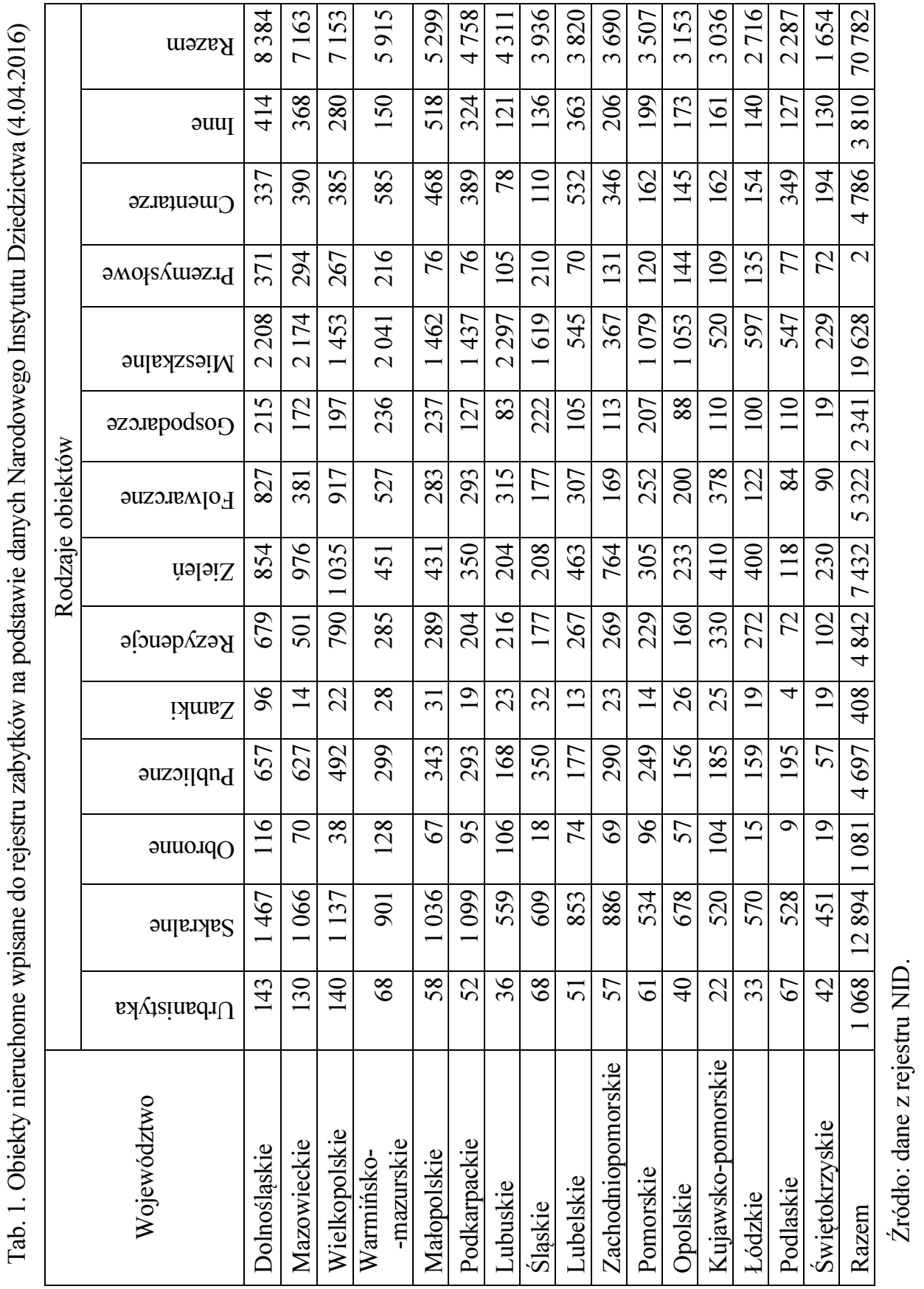


Województwo świętokrzyskie, zajmujące w tej analizie najniższą pozycję, jest także obszarem obfitującym w bogactwa naturalne o burzliwych dziejach historycznych, które wywarły znaczący wpływ na zasoby dziedzictwa kulturowego tego regionu. Miasta, takie jak: Kielce, Sandomierz, Opatów, to jedne z tych organizmów miejskich, które w całości zostały wpisane na listę zabytków, jako posiadające zabytkowy układ urbanistyczny. W związku z tym rodzi się pytanie: dlaczego w tej przestrzeni jest tak mało zabytków? Większość obszaru (ok. 62\%) to tereny zielone i uprawne. Północno-wschodnią część zajmuje Wyżyna Sandomierska, na której zboczach zaczyna się Puszcza Sandomierska. Znaczną część regionu zajmują Góry Świętokrzyskie, przecinające teren całego województwa z południowego zachodu na północny wschód. $\mathrm{Na}$ terenie gór w poprzednich wiekach znajdowała się prastara Puszcza Świętokrzyska, która obecnie zajmuje znacznie mniejszy obszar niż kiedyś. Jednak nadal teren ten uznawany jest za jeden $\mathrm{z}$ najbardziej zielonych, czystych ekologicznie. Mała gęstość zaludnienia, średniej wielkości miasta i nieliczne wsie - to teraźniejszy krajobraz województwa świętokrzyskiego (Harasimiuk, Rodzoś 2004).

Warunki geograficzne, a przede wszystkim złożoność procesów historycznego rozwoju poszczególnych części naszego kraju, widoczne są bardzo wyraźnie w strukturze rodzajowej występujących w nich obiektów zabytkowych (tab. 1). W większości regionów wojewódzkich (w 12) największy udział wśród obiektów mają budowle mieszkalne. Dotyczy to w szczególności województwa lubuskiego (ponad 53\%) i śląskiego (41\%). Wysoki odsetek wśród ogólnej liczby mają też w naszym kraju obiekty sakralne, a więc głównie kościoły katolickie oraz cerkwie obrządku wschodniego. Stanowią one najważniejszą grupę zabytków w pięciu województwach słabiej zurbanizowanych, ze znacznym udziałem rozproszonego osadnictwa wiejskiego. Dwa z nich - województwo lubelskie i badane w tym artykule podkarpackie - mają specyficzną sytuację związaną z położeniem na pograniczu wschodnim, tj. w miejscu, w którym współistniały dwa wyznania chrześcijańskie oraz judaizm. W rezultacie w wielu miejscowościach leżących na owym terenie, nawet tych o niewielkiej liczbie mieszkańców, budowano obok siebie kościoły, cerkwie i synagogi. W województwie podkarpackim znajduje się ponad 1000 obiektów sakralnych i w stosunku do jego powierzchni jest ich tam najwięcej w porównaniu do innych polskich województw. Wśród obiektów sakralnych są świątynie rzymskokatolickie, cerkwie greckokatolickie i prawosławne oraz nieliczne zachowane synagogi żydowskie. Budowle te świadczą o wielokulturowym dziedzictwie obszaru Podkarpacia. 


\section{Geograficzne i historyczne uwarunkowania rozmieszczenia zabytkowych obiektów sakralnych w województwie podkarpackim}

\subsection{Związek rzeźby terenu, sieci rzek i kompleksów leśnych z lokalizacją obiektów zabytkowych}

W obrębie prowincji zachodniokarpackiej na obszarze województwa znajduje się podprowincja Podkarpacie Północne, makroregion Kotliny Sandomierskiej. Jest to teren ukształtowany w okresie miocenu w wyniku akumulacji morskiej. Cała Kotlina Sandomierska położona jest w prawym dorzeczu Wisły, do której zlewiska uchodzą rzeki z obszaru województwa podkarpackiego, tj. Wisłoka i San. Najwyższe punkty na terenie kotliny wznoszą się do $280 \mathrm{~m}$ n.p.m., natomiast najniższe punkty są położone na wysokości około $200 \mathrm{~m}$ n.p.m. Gleby należą do niezbyt urodzajnych, przeważnie są to gleby bielicowe, natomiast mało jest gleb brunatnoziemnych (Fedan 2007). Większość mezoregionów Kotliny Sandomierskiej położonych jest na piaskach rzecznych, tworzących w niektórych miejscach wydmy mające do $25 \mathrm{~m}$ wysokości. $\mathrm{Z}$ tego powodu w średniowieczu obszar ten pokrywały wielkie lasy, których pozostałością są: Puszcza Sandomierska, Lasy Janowskie, Puszcza Solska i Lasy Sieniawskie (Kondracki 2009).

Druga z podprowincji to Zewnętrzne Karpaty Zachodnie, w tym makroregion Pogórza Środkowobeskidzkiego i Beskidów Środkowych, w których skład wchodzi położony na granicy Polski i Słowacji mezoregion Beskid Niski. W obrębie województwa podkarpackiego znajdują się, oprócz Pogórza Rożnowskiego, wszystkie mezoregiony wchodzące w skład makroregionu Pogórza Środkowobeskidzkiego. Obszar ten stanowi przejście pomiędzy strukturami tektonicznymi Karpat Zachodnich i Wschodnich. Cechą charakterystyczną jest zmiana kierunku pasm górskich na południowo-wschodni. Odmienna roślinność i układ pięter, występujące w partiach szczytowych rozległe łąki górskie, zwane połoninami - to kolejne charakterystyczne cechy Karpat Wschodnich, w tym grupy górskiej Bieszczadów. Za granicę Karpat Zachodnich i Wschodnich uważa się doliny Sanu, Osławy, Osławicy, Przełęcz Lupkowską oraz dolinę Laborca. Zewnętrzne Karpaty Zachodnie i Wschodnie zbudowane są ze zlepieńców i łupków, a także piaskowców określanych łącznie jako flisz. W północnej części Karpat Zachodnich powstały pogórza pocięte, na których obszarze wysokości względne dochodzą do 100-150 m. Natomiast w pasmach górskich dochodzą one nawet do $1000 \mathrm{~m}$ (Malarz 2003).

Region Wyżyny Lubelsko-Lwowskiej obejmuje północno-wschodni skrawek województwa. W jego granicach znalazł się mezoregion Roztocza Wschodniego. $\mathrm{Z}$ uwagi na położenie geograficzne w strefie tzw. rubieży klimatyczno-roślinnej 
Wyżyna Lubelska należy do strefy mieszanych lasów liściastych. Obszar Roztocza to pasmo wzniesień z pozostałościami osadów morskich z okresu miocenu. Wysokość względna wału Roztocza dochodzi do 100-150 m (Burczyński 2002). Sieć rzeczna jest tutaj rozwinięta nierównomiernie. Wyodrębnia się duże doliny rzeczne, m.in. Tanwi, jak i krótkie, wcięte w stoki dolinki, m.in. Brusieńki czy Radrużki.

Województwo podkarpackie w krajobrazie Polski wyróżnia się wysokim odsetkiem przestrzeni lesistych, które wykazują znaczne zróżnicowania w układzie przestrzennym. Ten ważny czynnik przyrodniczy wywarł znaczny wpływ na układ sieci osadniczej zarówno w wiekach poprzednich, jak i w XX w. Operacje związane z przesiedleniem ludności z tej części kraju w wyniku postanowień poczdamskich po zakończeniu II wojny światowej w szczególny sposób dotknęły terenów południowo-wschodnich województwa, a mianowicie Beskidu Niskiego i Wschodniego. Opuszczone wsie, dawne pola i sady zmieniły się w łąki, a następnie w lasy. W wyniku sukcesji wtórnej przyroda zajęła na tym obszarze miejsce człowieka.

W dobie wczesnohistorycznej jako granicę naturalną wykorzystywano puszcze, bagna i łańcuchy górskie. Na terenie dawnej puszczy sandomierskiej, leżącej między ramionami Wisły i Sanu a progiem Pogórza Karpackiego, funkcję takiej granicy naturalnej pełniły lasy, które oddzielały ten teren od ziem sąsiednich plemion. W średniowieczu cały prawobrzeżny obszar Wisły, począwszy od północy od doliny Wisły, poprzez nizinę sandomierską, następnie wierzchowiny Pogórza, aż po grzbiety Pogórza Karpackiego na południu, zajmowała olbrzymia puszcza. Była ona wspomnianą naturalną granicą pomiędzy terytoriami polskimi a ruskimi na wschodzie, a także stanowiła barierę na południu dla ludności pochodzenia węgierskiego. Jedynymi obszarami osadnictwa były wówczas doliny Wisły, Wisłoki i Sanu, a także kotliny śródbeskidzkie. Doliny te, ułożone południkowo, były stałymi szlakami migracyjnymi i handlowymi. Żywe kontakty handlowe i kulturowe z terenami na południu i północy Polski przyczyniały się do ich szybkiego rozwoju gospodarczego. Na obszarze dolin rzecznych występowały urodzajne gleby, które sprzyjały rolnictwu, a co za tym idzie - lokacji miast (będących skupiskami handlu) i okalających je wsi (których główną funkcją było rolnictwo).

W obecnych czasach wzdłuż doliny Sanu biegnie też ważny szlak komunikacyjny z Przemyśla do Sandomierza, w poprzednich wiekach istotny także pod względem handlowym. Obecnie również odgrywa on znaczącą rolę w komunikacji międzynarodowej. 
Lokacja wzdłuż Sanu takich miast, jak Przemyśl i Jarosław, a także ich znaczenie jako ośrodków gospodarczych i kulturalnych miały bezpośredni związek właśnie z przebiegającymi tamtędy traktami handlowymi. Przemyśl od początku swego istnienia był ważnym węzłem komunikacyjnym. Miasto jest bowiem usytuowane w miejscu o szczególnych walorach komunikacyjnych i obronnych. Zbiegają się tam granice regionów fizycznogeograficznych, etnicznych, kulturowych, a także ekonomicznych i politycznych. Dorzecze Wisłoka, leżące nieco na uboczu tego głównego szlaku handlowego ze wschodem, w czasach wczesnohistorycznych pozostawało obszarem słabo zaludnionym. Jednak także w tym pasie, ciągnącym się od zachodu na wschód, można było dostrzec dwie przerwy, biegnące wzdłuż doliny Wisłoka i następnie Sanu. Te doliny, zasiedlone znacznie później, wyznaczały dwa strategiczne szlaki w kierunku Rusi.

Prastara droga piastowska, wiodąca z Polski na Ruś, biegła z zachodu na wschód przez tzw. Bramę Łańcucką, wykorzystując naturalną przerwę między puszczą Karpacką a Sandomierską. Z powodu braku naturalnych barier w postaci puszcz i zróżnicowanej wysokości stanowiła ona bramę umożliwiającą migrację ludów ze wschodu. Szlak ten, zwany też karpackim, odegrał istotną rolę w procesie miastotwórczym m.in. Dębicy, Pilzna, Rzeszowa, Łańcuta, Jarosławia i Przemyśla.

Ekspansja człowieka na obszary zalesione, rozpoczęta w średniowieczu i sięgająca XIX w., spowodowała znaczny spadek lesistości. Przykładem może być obszar Bieszczadów, w dzisiejszych czasach uważany za dziki i mocno zalesiony, na którym w wyniku eksploatacji i zasiedlenia odnotowano spadek lesistości z 85\% w XVI w. do $38 \%$ pod koniec XIX w. Krajowe dane liczbowe dotyczące lesistości znacznie poprawiły się w latach po II wojnie światowej. Dzięki powojennej akcji zalesieniowej na obszarze gmin bieszczadzkich wskaźnik wzrósł do $80 \%$ (Marszatek 2010).

Podsumowując opis czynników wypływających na osadnictwo tych ziem, należy podkreślić, że dwa główne szlaki przecinające obszar pradawnej puszczy zostały wytyczone południkowo wzdłuż dolin rzecznych i równoleżnikowo wzdłuż urodzajnych gleb lessowych. Z kolei wzdłuż szlaków lokowane były miasta otoczone wsiami. Wymienione powyżej uwarunkowania geograficzne w szczególny sposób zarysowują się pod względem liczby i typu obiektów, które pozostały na terenie województwa podkarpackiego.

Rozpatrując badany obszar w kontekście przestrzennego zagęszczenia wybranych obiektów zabytkowych względem uwarunkowań fizjograficznych i etnicznych, zauważa się następującą prawidłowość: wraz z wysokością maleje liczba tego rodzaju budynków, a pośród istniejących dominującą grupę stanowią cerkwie 
(ryc. 2). Takie zróżnicowanie przestrzenne, ilościowe i strukturalne jest następstwem barier hipsometrycznych oraz uwarunkowań historycznych. Interesującym zjawiskiem na terenach podgórskich i górskich jest przestrzenna lokalizacja analizowanych sakralnych obiektów zabytkowych, w przypadku których warunki zabudowy były determinowane, a nawet wymuszane przez istniejące formy rzeźby. Na rodzaj lokowanej budowli, jej wielkość oraz przeznaczenie wpływały: układ grzbietów i kąt nachylenia stoków, stopień ich dostępności i połączeń komunikacyjnych z bliższym i dalszym otoczeniem.

Lokalizacja cerkwi na wzniesieniach ma wymiar praktyczny i zarazem symboliczny. Aspektem praktycznym takiego umiejscowienia budowli była możliwość odprowadzania wody deszczowej, która spływając ze stoku, nie gromadziła się wokół fundamentów. Symboliczny wymiar wiązał się z tradycją, zgodnie z którą dom boży powinien stać wyżej niż domy mieszkańców danej miejscowości. Już w czasach pogańskich wzniesienia pełniły funkcję miejsc kultu z racji dominacji nad otoczeniem i zarazem bliskości nieba. Warto zaznaczyć, że najstarsze świątynie chrześcijańskie często budowane były w miejscach, w których wcześniej znajdowały się pogańskie miejsca kultowe - kręgi, święte gaje, cudowne źródła itp. Jednym z ważniejszych powodów lokalizacji cerkwi na wzniesieniach była również funkcja obronna. Szczególnie dotyczyło to obiektów klasztornych, przykładem może być cerkiew w Uluczu (Bańkosz 2010).

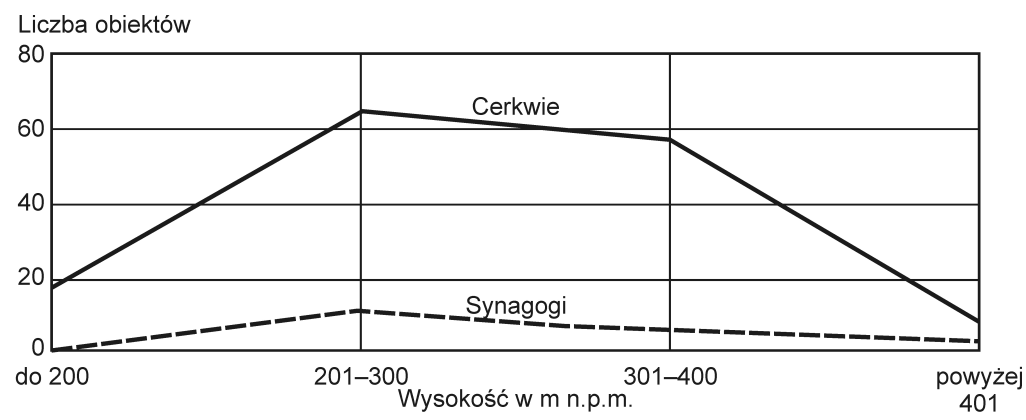

Ryc. 2. Rozmieszczenie obiektów zabytkowych względem wysokości n.p.m.

Źródło: opracowanie własne

Obecnie obszar województwa podkarpackiego w 38,1\% zajmują lasy. Dla porównania średnia lesistość Polski wynosi 29,5\%. Jedynym województwem, które wyróżnia się wyższą lesistością, jest lubuskie (wynosi tam ona 49,2\%). Najmniej lasów rośnie w środkowej części województwa podkarpackiego, tj. na terenie dawnego województwa rzeszowskiego - $24 \%$ (najniższe zalesienie odnotowano 
w powiecie łańcuckim - 20,5\%). Najwyższy stopień lesistości jest w podregionie południowym - ponad $60 \%$ (najwięcej lasów występuje w powiecie bieszczadzkim - 68,8\%) (Województwo podkarpackie... 2016). Porównując lesistość powiatów do gęstości zaludnienia, można stwierdzić, że jest ona odwrotnie proporcjonalna.

Region zamieszkuje 2,1 mln osób, co stanowi 5,5\% ludności kraju. Rozmieszczenie przestrzenne ludności jest bardzo zróżnicowane. $\mathrm{Na} 1 \mathrm{~km}^{2}$ powierzchni we wschodnich powiatach województwa przypada poniżej 45 osób (powiat bieszczadzki - 19 osób, leski - 32 osoby, lubaczowski - 43 osoby na $1 \mathrm{~km}^{2}$ ), natomiast w powiatach położonych w środkowo-zachodniej części województwa na $1 \mathrm{~km}^{2}$ przypada powyżej 140 osób (powiat rzeszowski - 144 osoby, mielecki - 155 osób, dębicki - 174 osoby oraz łańcucki - 177 osób na $1 \mathrm{~km}^{2}$ ) (Województwo podkarpackie... 2016).

\subsection{Wpływ granic politycznych i oddziaływań kulturowych na przestrzenne rozmieszczenie świątyń}

Problem granicy między Polską a Rusią ma aspekt geograficzny, społeczny, polityczny, ekonomiczny i militarny. Zagadnienie przebiegu tej granicy stanowi kwestię sporną z uwagi na jego częste zmiany od czasów pradawnych. Brak naturalnej bariery od strony wschodniej na obszarze obecnego województwa podkarpackiego od wieków powodował konflikty, a nawet wojny o tereny znajdujące się w pasie tzw. pogranicza.

Polska graniczyła z Rusią od początków istnienia państwa polskiego, czyli od $\mathrm{X}$ w. Od tego czasu trwały także spory o ziemie wschodniej Małopolski pomiędzy tworzącymi się właśnie państwami - Polską i Rusią Kijowską. W 981 r. należące do plemienia Lędzian ziemie leżące nad Sanem i Bugiem zostały przyłączone do Rusi. Jak podaje kronikarz ruski Nestor: ,roku 981 poszedł Włodzimierz ku Lachom i zajął grody ich: Przemyśl, Czerwień i inne grody..." (Marszałek 1993).

Do XIV w. wschodnia część województwa, zwana Grodami Czerwińskimi, leżała w granicach Rusi, a następnie Księstwa Ruskiego. Jednakże w tym okresie owe ziemie wielokrotnie były przyłączane do Polski i ponownie wcielane do terytorium Rusi. W XIV w., za panowania Kazimierza Wielkiego, nastąpiło trwałe przyłączenie Grodów Czerwieńskich (część wschodnia obecnego województwa podkarpackiego) do państwa polskiego. Wyludnione w wyniku wieloletniego znajdowania się pod jarzmem tatarskim tereny Rusi Kijowskiej ożywiła ludność polska, thumnie napływająca na te obszary. Nastąpił intensywny rozwój osadnictwa na terenach Rusi Czerwonej, którą zasiedlano nie tylko ze względu na stra- 
tegiczne położenie, ale także z uwagi na bogactwa mineralne (m.in. złoża soli), gęste lasy (materiał budowlany), gleby dobre pod uprawę i rozległe pastwiska. Magnesem była także bogata sieć rzeczna.

Struktura wyznaniowa w miastach zmieniała się pod wpływem napływającej ludności. Liczba katolików ogólnie wzrosła w ówczesnym czasie z uwagi na fakt nowego osadnictwa i gwałtownego rozwoju istniejących miast. Pokojowe stosunki z Litwą także wpływały korzystnie na rozwój gospodarczy kraju polskiego. Swobodny przepływ ludności i rozwijająca się wymiana handlowa sprzyjały także wymianie kulturowej.

Zaczęto zasiedlać też bezludne tereny górskie, które król Kazimierz oddał możnowładcom i Kościołowi. Część obszaru Bieszczadów i Pogórza Przemyskiego została przekazana wpływowemu rodowi Kmitów, natomiast wschodnią część Beskidu Niskiego oddano biskupom krakowskim (Michniewscy 2003). Wspomniany teren do połowy XIV w. znajdował się w granicach Rusi, w związku $\mathrm{z}$ tym religią dominującą było tu chrześcijaństwo w obrządku wschodnim. Po przyłączeniu tych ziem do Polski nie zmieniła się ich struktura wyznaniowa. Ludność zamieszkująca tereny Beskidu Niskiego i Bieszczadów zajmowała się głównie rolnictwem i wypasem. W XVI w. miała miejsce kolonizacja ludności wołosko-ruskiej wyznającej prawosławie ${ }^{2}$. Pasterze wołoscy, wędrujący z obszarów dzisiejszej Rumunii, mieszali się po drodze z ludami ruskimi zamieszkującymi te tereny. Sprzyjała temu przede wszystkim wspólna religia. Wskutek wpływu ludności zamieszkującej te tereny osadnicy wołoscy nie zdołali zachować odrębności etnicznej i kulturowej. Jedna z teorii dotyczących powstania poszczególnych grup etnicznych na obszarze Podkarpacia mówi o tym, że z kolonizacji wołoskiej wywodzą się Łemkowie i Bojkowie. Łemkowie, zamieszkujący tereny Beskidu Niskiego, określani byli jako wędrowni pasterze, i to dzięki nim na wspomnianych terenach powstało tak wiele charakterystycznych cerkwi (m.in.: w Krempnie, Turzańsku, Rzepedzi). Druga z grup etnicznych, Bojkowie, to górale ukraińscy, którzy osiedlili się głównie w paśmie Bieszczadów. Specyficzne cerkwie bojkowskie zachowały się jeszcze m.in. w Równi, Smolniku i Liskowatem.

Wiek XV i XVI to także okres migracji Rusinów ze wschodu na zachód, głównie z tzw. Zakarpacia na obszary obecnych województw podkarpackiego i małopolskiego. W związku z napływem nowych osadników wołosko-ruskich - przede wszystkim na tereny górskie Bieszczadów - dominującą religią było tam prawosławie.

${ }^{2}$ Wołosi to wywodzące się z obszaru Bałkanów, pasterskie ludy koczownicze, które począwszy od XIII w., zaczęły wędrować wraz ze swymi stadami wzdłuż łuku Karpat (Michniewscy, Duda 2003). 
Kultura obrządku wschodniego miała znaczący wpływ na krajobraz kulturowy obszaru południowo-wschodniej Polski. Cechą Kościoła wschodniego było budowanie świątyni w każdej wsi. Obfitość lasów na tym terenie wpłynęła na to, że jako podstawowego materiału budowlanego używano drewna. Budowniczymi świątyń byli miejscowi cieśle, którzy stworzyli obiekty reprezentujące różnorodne style i techniki. W tym okresie, w związku z zasiedlaniem istniejących, a także tworzeniem nowych wsi, powstało wiele drewnianych cerkwi, które przetrwały do naszych czasów. Są to m.in. cerkwie należące do najstarszych na badanym obszarze, znajdujące się w: Radrużu, Gorajcu, Chotyńcu, Uluczu i Kurhelu Wielkim. Jednym z najciekawszych zachowanych obiektów sakralnych Kościoła wschodniego jest murowana cerkiew w Posadzie Rybotyckiej, będąca najstarszym budynkiem obronnym tego rodzaju w Polsce (przełom XIV i XV w.).

Zawarcie w 1596 r. unii w Brześciu nad Bugiem pomiędzy prawosławnymi biskupami polskimi (z wyjątkiem przemyskiego i lwowskiego) a przedstawicielami papieża i jezuitów spowodowało rozłam wewnątrz Kościoła wschodniego. Prawosławni, którzy uznawali zwierzchność papieża, nazywani byli unitami, a w późniejszych wiekach grekokatolikami,. Drugi odłam, podległy patriarsze konstantynopolitańskiemu, tworzyli wyznawcy nazywani pierwotnie dyzunitami, a następnie prawosławnymi. Przyjęcie unii brzeskiej przez większość biskupów prawosławnych wywołało na obszarze obecnego województwa podkarpackiego zajadłe walki religijne. W tym okresie powstawały cerkwie o charakterze obronnym. Przykładem jest cerkiew w Nowych Sadach z 1655 r.

Okres panowania króla Kazimierza Wielkiego to także czasy sprzyjające osiedlaniu się na tych terenach ludności żydowskiej. Prześladowana w krajach Europy Zachodniej, od momentu krucjat w 1096 i 1145 r. napływała systematycznie na tereny polskie, gdzie znalazła sprzyjające warunki do osadzenia się. Osiedlaniu się sprzyjała głównie polityka Kazimierza Wielkiego, który w połowie XIV w. określił status Żydów przywilejami (mogli zachować własną religię, własne prawa, swobodnie prowadzić handel). Taka polityka króla związana była $\mathrm{z}$ celowym zgromadzeniem w Polsce, a w szczególności na zubożałych terenach wschodnich, kapitału, który podniósłby przemysł i wzbogacił Skarb Państwa. Najstarsza wzmianka o gminie żydowskiej na terenie Polski pochodzi z XI w. i odnosi się do Przemyśla. Informacja ta została zamieszczona w zaginionym dziele Jehudy ha-Kohena (Błoński 2008). Żydzi osiedlali się głównie w miastach, jednak w niektórych z nich wprowadzono różnego rodzaju ograniczenia, wynikające głównie $\mathrm{z}$ obawy przed konkurencją $\mathrm{w}$ handlu. Między innymi w miastach królewskich: Krośnie, Jaśle, Pilźnie i Dębowcu, wydano przywilej de non tolerandis Judaeis, 
zabraniający ludności żydowskiej osiedlania się tam (Potocki 2004). Także w niektórych z miast stanowiących własność prywatną wprowadzono różnego rodzaju ograniczenia dotyczące osadnictwa żydowskiego, m.in.: w Jarosławiu w $1571 \mathrm{r}$. Zofia z Odrowążów Kostkowa wydała przywilej nakazujący osadnikom żydowskim zajmowanie tylko dwóch domów (Orłowicz 1921). Jednak w następnych wiekach ludność żydowska, która wcześniej zamieszkiwała tylko sześć miast, osiedliła się na stałe już w trzydziestu miastach obecnego województwa podkarpackiego. Pod koniec XVI w. w Małopolsce mieszkało około 7000 osób pochodzenia żydowskiego, natomiast na terenie Rusi Czerwonej - dwa razy więcej. Natomiast pod koniec XVIII w. Żydzi polscy byli najliczniejszą diasporą na świecie, liczącą około 900 tys. osób (Potocki 2004). Największe gminy żydowskie na terenie obecnego województwa podkarpackiego znajdowały się w Przemyślu i w Jarosławiu.

Granice Polski w następnych dziesięcioleciach nadal ulegały znacznym zmianom, jednakże obecne tereny województwa podkarpackiego pozostawały pod rządami królów polskich aż do rozbiorów w XVIII w. Ruś Czerwona została trwale przyłączona do Polski. Prawdopodobnie ów fakt przyśpieszył proces polonizacji tych terenów. Analizując badany obszar pod względem oddziaływań kulturowych do końca XVIII w., zauważa się znaczny wpływ zarówno kultury żydowskiej, jak i ruskiej. $\mathrm{W}$ omawianym okresie powstało wiele $\mathrm{z}$ istniejących do dzisiaj obiektów sakralnych, świadczących o wielokulturowości tego regionu.

W wyniku pierwszego rozbioru Polski w 1772 r. ziemie lwowska, przemyska, chełmska i bełska znalazły się w zaborze austriackim. Na zajętych terenach utworzono Księstwo Galicji i Lodomerii. Austriacy sprzyjali ludności żydowskiej zamieszkującej miasta w granicach zaboru, a nawet stwarzali jej korzystne warunki do uczestnictwa w życiu gospodarczym i kulturalnym kraju. Podczas panowania austriackiego w Jarosławiu ludność żydowska stanowiła jedną czwartą mieszkańców miasta, natomiast w Przemyślu społeczność niemal w połowie była tworzona przez Żydów. Sprzyjali oni tendencjom germanizacyjnym zaborcy na zajętych terenach, natomiast Austriacy znieśli wszelkie ograniczenia związane z osadnictwem żydowskim. Także Kościół unicki był oficjalnie uznawany, a nawet popierany w zaborze austriackim. Warto także zaznaczyć, że to właśnie cesarzowa austriacka Maria Teresa nakazała nazywać unitów grekokatolikami, co miało świadczyć o zrównaniu ich praw z katolikami rzymskimi (Bańkosz 2010). Większość $\mathrm{z}$ istniejących na badanym obszarze cerkwi powstała właśnie pod rządami austriackim.

Wojska austriackie, które zajęły miasta, nie miały gdzie umieścić swoich żołnierzy. Brakowało również miejsca na urzędy. Rząd austriacki nie myślał o bu- 
dowaniu nowych obiektów, ponieważ znalazł łatwiejszy i ekonomicznie korzystniejszy sposób, mianowicie umieścił koszary, magazyny wojskowe i urzędy w dawnych klasztorach. Kasata klasztorów na obszarze zaboru austriackiego nastąpiła w latach 1782-1789. W ten sposób zlikwidowano wiele klasztorów jezuitów, benedyktynek, franciszkanów i innych. Nie oszczędzono nawet kościołów i cerkwi. Zamknięcie szkół, zniesienie towarzystw i bractw religijnych oraz wprowadzenie na ich miejsce szkół niemieckich było powodem postępującej germanizacji i zaniku kultury oraz obyczajów rdzennych mieszkańców tych ziem.

Po 1918 r., w okresie kiedy odradzało się państwo polskie, ludność zamieszkująca tereny obecnego województwa podkarpackiego była bardzo podzielona zarówno narodowościowo, jak i kulturowo. Według spisu z 1931 r. w II Rzeczpospolitej mieszkało ok. 32 mln osób, z czego ludność Polska stanowiła 68,1\%, Ukraińska - 13,9\%, Żydowska - 9,8\%, Białoruska-3,1\%, Niemiecka-2,3\%, a pozostałe narodowości (Litwini, Czesi, Słowacy, Ormianie i Tatarzy) - 2,8\% (Sienkiewicz, Gryciuk 2008).

$\mathrm{Na}$ badanym obszarze narastał ostry konflikt polsko-ukraiński. Pod koniec wojny wśród unitów pojawiły się silne tendencje separatystyczne. W latach 19181920 istniało niepodległe państwo ukraińskie, w którym główną religią było wyznanie greckokatolickie. Trwały walki o poszczególne miasta i wioski Podkarpacia (m.in.: o Przemyśl i Lwów), w których mieszkała ludność ukraińska. W granicach odrodzonej Polski znalazła się także spora liczba wiernych prawosławnych, pochodzących z ziem będących częścią dawnego zaboru rosyjskiego. Kwestią sporną był problem użytkowania cerkwi, które stanowiły własność Kościoła greckokatolickiego. Były one budowane przez ludność miejscową oraz wyposażane i remontowane za pieniądze wiernych. W związku z powyższym prawosławni budowali nowe cerkwie.

Odmiennie układały się stosunki polsko-żydowskie w międzywojniu. Ludność żydowska podczas niewoli brała czynny udział w walkach o niepodległość, jak również wniosła znaczący wpływ w rozwój kultury i nauki w okresie powojennym. W 1939 r. w Polsce mieszkało 3300 tys. przedstawicieli społeczności żydowskiej, co stanowiło około 10\% ogółu ludności kraju (Potocki 2004). Pod względem liczby ludności żydowskiej województwo lwowskie, w którego granicach znajduje się obecnie województwo podkarpackie, było trzecim co do koncentracji tej narodowości po warszawskim i łódzkim.

Z chwilą wybuchu II wojny światowej rozpoczęła się eksterminacja ludności żydowskiej. Tworzono getta w miastach (m.in. w Przemyślu, Rzeszowie), w których gromadzono ludność żydowską, a następnie przewożono do obozów koncen- 
tracyjnych lub rozstrzeliwano. Zagłada narodu żydowskiego doprowadziła do prawie całkowitego zaniku tej narodowości na obszarze województwa podkarpackiego. Według danych z 1945 r. na terenie dawnego województwa rzeszowskiego mieszkało jedynie 1644 osób narodowości żydowskiej, co stanowiło zaledwie $0,16 \%$ stanu sprzed II wojny światowej (Potocki 2004). Niestety w następnych latach, z uwagi na politykę państwa, większość Żydów, którzy przetrwali Holocaust, wyemigrowała do Stanów Zjednoczonych, Kanady lub Izraela.

Okupanci niemieccy dewastowali także wszystkie obiekty świadczące o kulturze judaistycznej. Do 1945 r. zniszczono, podpalono lub wysadzono większość synagog. W okresie powojennym świątynie, które przetrwały, stały opuszczone, w znacznym stopniu także zrujnowane. Brak użytkowników oraz odpowiedniego zabezpieczenia doprowadził w kilku przypadkach do rozbiórki z nakazu władz (m.in. synagoga w Lubaczowie, Krośnie, stara synagoga w Przemyślu). Obiekty, które jednak przetrwały, służyły często jako magazyny. Były to m.in. synagogi w Cieszanowie, Wielkich Oczach, Dukli, Lesku i w Łańcucie. Zachowane do czasów współczesnych ślady kultury żydowskiej, obecnej na terenach dzisiejszego województwa podkarpackiego przez ponad 500 lat, to: zaledwie kilkanaście synagog, częstokroć będących w stanie ruiny, kilkadziesiąt zaniedbanych kirkutów oraz niewielkie zbiory judaików.

Okres przypadający na lata po II wojnie światowej to najostrzej zarysowane ruchy migracyjne właśnie na terenach obecnego województwa podkarpackiego i terenów mu przyległych w paśmie granicy polsko-ukraińskiej. Powodów owej migracji było wiele, zaczynając od najważniejszych czynników politycznych, czyli przymusowych wysiedleń, związanych ze zmianą granic, poprzez czynniki ekonomiczne i kulturowe. Ruchy migracyjne objęły tutaj ok. 1 mln osób z ZSRR do Polski, natomiast z Polski do ZSRR przesiedlono 480 tys. Porównując opisane ruchy migracyjne, dochodzi się do wniosku, że migracja z ZSRR do Polski na terenie południowo-wschodnim (obecne województwo podkarpackie, małopolskie i lubelskie) wyniosła ok. 43\% całego ruchu repatriacyjnego z ZSRR do Polski i aż 92\% ruchu repatriacyjnego z Polski do ZSRR (Maryański 1969). Bezpośrednim rezultatem tych działań było wyludnienie dużych obszarów południowo-wschodniej części kraju. Dodatkowym powodem zmian demograficznych były również działania band ukraińskich UPA w latach 1945-1947, które doprowadziły do bezpowrotnego wyniszczenia wielu wsi w pasie pogranicza polsko-ukraińskiego. W odwecie za terrorystyczną działalność tych band władze Polski przeprowadziły w 1947 r. kolejną akcję przesiedleńczą, tzw. akcję Wisła, w wyniku której na tereny Ziem Zachodnich przeniesiono ponad 140 tys. osób (Pisuliński 2008). Niestety decyzją władz polskich przesiedlono także rdzennych mieszkań- 
ców Beskidu Niskiego - Łemków, którzy jako ludność posługująca się językiem ruskim, należąca do wyznania greckokatolickiego, zostali uznani także za Ukraińców.

W wyniku oddziaływania wymienionych czynników na południowo-wschodnim pograniczu powojennej Polski liczba ludności zmniejszyła się o ponad 2/3. Według spisu z roku 1931 na obszarze województwa rzeszowskiego mieszkało 521 tys. osób (prawdopodobnie w chwili wybuchu II wojny światowej ta liczba dochodziła do 580 tys.), natomiast spis przeprowadzony w 1950 r. wykazał jedynie 176 tys. (Maryański 1963).

Najgorzej przedstawiał się krajobraz w paśmie pogranicza, czyli na terenie Beskidu Niskiego i Bieszczadów. Dane z powojennego spisu wykazały aż 137 opuszczonych wsi oraz 34 zachowane jedynie w stanie szczątkowym. Według wspomnianego przedwojennego spisu z $1931 \mathrm{r}$. na tym terenie mieszkało 43,7 tys. osób (w większości wyznania greckokatolickiego). Powojenny obraz tego regionu ukazuje resztki trzech wsi (Cisna, Wola Mnichowa i Wisłok Wielki) z 354 mieszkańcami (Maryański 1963).

Przez wiele następnych dziesięcioleci - a w niektórych przypadkach także po dziś dzień - po rdzennych mieszkańcach tych terenów pozostały tylko ślady dawnych osad, coraz bardziej zacierane przez przyrodę. Są to miejscowości położone w Beskidzie Niskim (m.in.: Polany Surowicze, Królik Wołoski, Darów), miejscowości bieszczadzkie (takie, jak: Caryńskie, Krywe, Tworylne) czy zlokalizowane na Pogórzu Przemyskim (Trójca, Arłamów, Łomna i in.), a także na obszarze Roztocza (np. Stare Brusno, Dziewięcierz czy Sieniawka) (Kłos 2010).

Wyludnione wsie, opuszczone domy, zniszczone w wyniku działań wojennych miasta - tak prezentował się krajobraz powojennej Polski południowo-wschodniej. Warto jednak zaznaczyć, że większość obiektów sakralnych, w tym szczególnie kościołów i cerkwi, przetrwała okres wojny. Jedynie znaczna część synagog została celowo zniszczona przez wojska niemieckie jeszcze w czasie trwania wojny. W powojennej Polsce od ochrony i zachowania dawnego dziedzictwa wielokulturowego ważniejsza była odbudowa szkół, szpitali i innych budynków użyteczności publicznej, niezbędnych do właściwego funkcjonowania kraju. Dlatego tak wiele obiektów sakralnych, które przetrwały okres wojny, najbardziej ucierpiało w latach powojennych. Brak opieki, celowa dewastacja albo rozbiórka dla zaspokojenia potrzeb materialnych to główne czynniki, które wpłynęły zasadniczo na krajobraz kulturowy południowo-wschodniej Polski po II wojnie światowej.

Zmiany demograficzne terenów pogranicza w szczególności wpłynęły na losy obiektów sakralnych obrządku wschodniego. Polacy przybywający na te obszary 
po wojnie bali się zasiedlać osady pozostałe po Ukraińcach. Z tych powodów przez wiele następnych lat obszar od tzw. górnego Sanu aż po linię kolejową Zagórz-Sanok pozostawał bezludny. Opuszczone wsie i nieużytkowane świątynie popadały w ruinę. Kolejnym powodem niszczenia obiektów sakralnych obrządku wschodniego była sytuacja prawno-polityczna Kościoła greckokatolickiego, który po wojnie został pozbawiony struktur i hierarchii, a co za tym idzie - osobowości prawnej i majątku ${ }^{3}$. Cerkwie zostały częściowo przejęte przez Kościół rzymskokatolicki. W latach 1951-1969 użytkowanych było 91 cerkwi przez parafie rzymskokatolickie, natomiast po 1970 r. były to już 133 obiekty ${ }^{4}$. Działania Kościoła katolickiego przyczyniły się do uratowania wielu cennych obiektów obrządku wschodniego, jednakże wnętrze świątyń, a w wielu przypadkach także zewnętrzne otoczenie zatraciło swój pierwotny wygląd z powodu adaptacji na potrzeby liturgii obrządku rzymskokatolickiego (wyrzucano i palono cenne ikonostasy, zamalowywano polichromie, burzono drewniane dzwonnice itp.). Do roku 1989 parafiom prawosławnym zostało przekazanych jedynie 17 cerkwi (m.in. cerkiew w Kalnikowie już w 1950 r.), a parafiom greckokatolickim oddano tylko trzy obiekty (w Olechowcu, Ustrzykach Dolnych i Jarosławiu). Niestety znaczna grupa świątyń została przejęta przez Skarb Państwa, który przekazał je miejscowym Państwowym Gospodarstwom Rolnym. W ten sposób przepiękne, często wielowiekowe cerkwie stawały się magazynami pasz i nawozów, a nawet służyły jako obory dla zwierząt. Część świątyń udało się uratować, przenosząc je z opuszczonych wsi na teren sąsiednich, zamieszkanych (np. cerkiew z Ropieńki przetransportowano do pobliskiej Wańkowej) lub do powstającego skansenu w Sanoku (cerkiew z Grąziowej, Rosolina i Ropek).

Wysoki odsetek cerkwi pozostawał nadal nieużytkowany, co przyczyniło się do dalszej dewastacji, a nawet celowych rozbiórek na materiał budowlany lub opał. W 1955 r., zgodnie z przyjętą uchwałą, rozpoczęto rozbiórkę wszystkich pozostałych na terenie kraju, nieużytkowanych obiektów obrządku wschodniego 5 . W wyniku tej starannie zaplanowanej akcji niszczenia cerkwi z nakazu władz na terenie Polski zlikwidowano ok. 350 obiektów obrządku wschodniego. Według wykazów konserwatorskich oraz materiałów z kurii biskupiej w Przemyślu na

${ }^{3}$ Ustawa z 6 maja 1945 r. o majątkach opuszczonych i porzuconych, DzU z 1945 r., nr 17, poz. 97 oraz Dekret z 5 września 1947 r. o przejściu na własność państwa mienia pozostającego po osobach przesiedlonych do ZSRR, DzU z 1949 r., nr 59, poz. 318.

${ }^{4}$ Dane zebrane na podstawie badań własnych.

${ }^{5}$ Uchwała nr 666 Prezydium Rządu z dnia 20 sierpnia 1955 r. w sprawie planowanej akcji usunięcia pozostałości zniszczeń wojennych w miastach i osiedlach, DzU z 1955 r., nr 92, poz. 1189. 
obszarze dawnego województwa rzeszowskiego przed II wojną światową znajdowały się 552 cerkwie, w tym 311 określanych jako zabytkowe (według dawnych kryteriów za zabytek uznawano tylko świątynie wybudowane przed 1850 r.). Akcje rozbiórkowe prowadzone były także w latach późniejszych drugiej połowy XX w. Warto zaznaczyć, że jedną z ostatnich cerkwi zlikwidowanych w „majestacie prawa" była XVIII-wieczna budowla tego typu w Bobrówce, rozebrana w 1988 r. pod pretekstem generalnego remontu. Podsumowując, do 1989 r. na terenie dawnego województwa rzeszowskiego usunięto 253 drewniane i murowane obiekty obrządku wschodniego, z czego tylko 13 zostało zniszczonych podczas działań wojennych, trwających na tych obszarach do 1947 r. (Brykowski 1997).

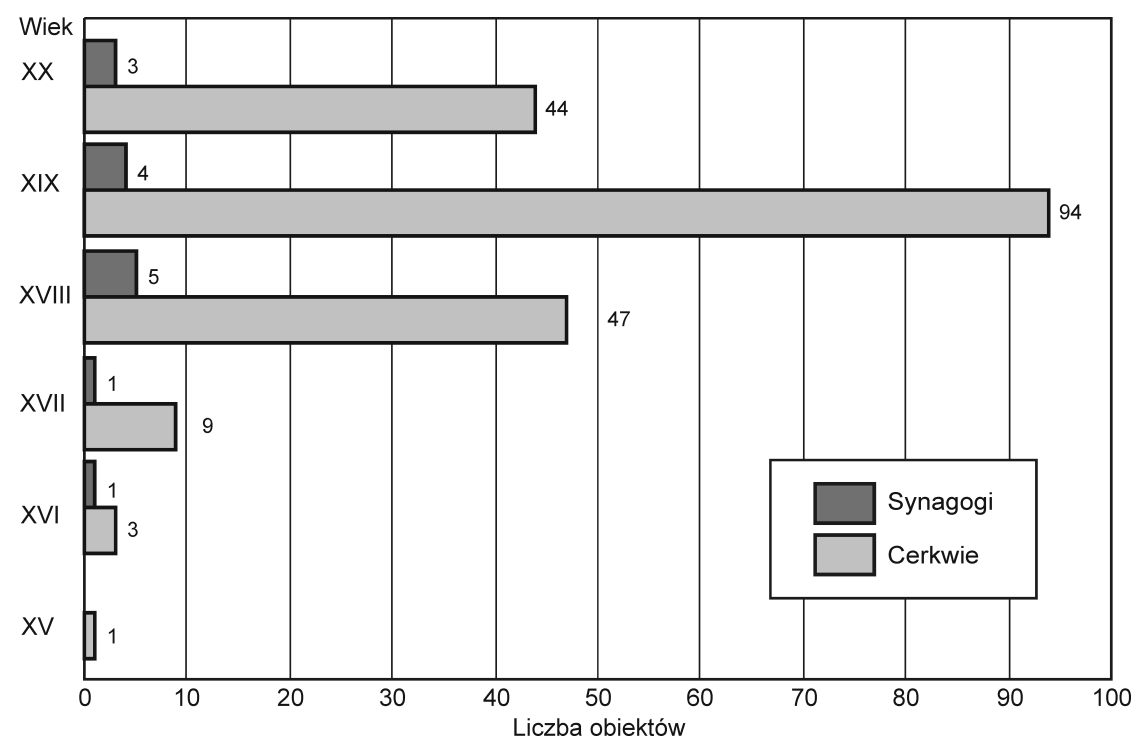

Ryc. 3. Chronologia obiektów sakralnych według okresów ich powstania Źródło: opracowanie własne

W wyniku działań wojennych, a w szczególności celowych i bestialskich akcji rozbiórkowych w okresie powojennym, trwających aż do 1989 r., bezpowrotnie utraciliśmy wielowiekowe dziedzictwo kulturowe, które na tych terenach zaznaczyło się w sposób szczególny poprzez istnienie w jednej miejscowości kościoła, synagogi i cerkwi. Krajobraz taki, typowy dla tego obszaru, teraz stał się unikatowy i przetrwał jedynie w kilku miejscowościach, w których nadal można zobaczyć te trzy świątynie obok siebie (m.in. w Wielkich Oczach i Cieszanowie). Zniszczone zostały kilkusetletnie synagogi i cerkwie, które zbudowali miejscowi rzemieśl- 
nicy. W szczególności ucierpiała architektura drewniana. Tymczasem każdy z tych obiektów był niepowtarzalnym dziełem sztuki. Według dostępnych danych w okresie powojennym zniszczono ponad 200 drewnianych cerkwi, w tym dwie pochodzące z XVI w. oraz dziewięć zbudowanych w XVII w. (Brykowski 1997). Niestety na terenie województwa nie zachowała się żadna drewniana synagoga. Wszystkie nie przetrwały wojennej pożogi lub przestały istnieć wskutek celowych podpaleń w okresie powojennym (m.in. synagoga w Jaćmierzu, Dubiecku). Zniszczono także wiele z najstarszych murowanych obiektów. Na ryc. 3 zaprezentowano stan liczebny zachowanych obecnie obiektów według kolejności ich powstawania.

\subsection{Wpływ historyeznych szlaków handlowych i nowożytnych szlaków komunikacyjnych na przestrzenną lokalizację badanych obiektów}

W średniowieczu, a także w czasach nowożytnych dogodne położenie Polski, niejako na styku dwóch odmiennych kultur i cywilizacji - Wschodu i Zachodu - czyniło z niej ważnego partnera i zarazem wroga na arenie politycznej i gospodarczej. W XIV w. przez obszar Królestwa Polskiego wiodły szlaki o ułożeniu południkowym, łączące porty czarnomorskie z portami bałtyckimi, oraz szlaki o ułożeniu równoleżnikowym, łączące Węgry i Bałkany z zachodnią Europą. Ze względu na strategiczne położenie tych obszarów (krzyżowały się tam i biegły tamtędy najważniejsze szlaki) trwały wieloletnie walki o ich przynależność. Tego typu regionem była Ruś Czerwona, a w szczególności takie miasta, jak: Jarosław, Przemyśl oraz Lwów, które leżały przy jednym z najważniejszych szlaków łączących Morze Czarne z Morzem Bałtyckim. Od czasów swojego powstania państwo polskie rywalizowało z Tatarami, Litwinami i Węgrami o przynależność tych terenów.

Takim pradawnym traktem, biegnącym przez obszar obecnego województwa podkarpackiego, był szlak bałtycko-czarnomorski, tzw. szlak solno-bursztynowy. Trasa tego kanału handlowego przebiegała w dwojaki sposób - jedna z dróg wiodła przez Toruń, Radom, Kazimierz, Lublin i Belz, natomiast druga - przez Toruń, Opatów, Sandomierz i Lubaczów. Na terenie obecnej Ukrainy szlak bałtycko-czarnomorski przebiegał przez Lwów, a następnie prowadził przez Kamieniec Podolski do portów czarnomorskich w takich miejscowościach, jak: Kaffa, Kilia i Białogród. Lokacja Lwowa przez Kazimierza Wielkiego była związana właśnie z lokalizacją pradawnej osady w miejscu krzyżowania się czterech ważnych europejskich szlaków handlowych - wspomnianego powyżej szlaku łączącego Bałtyk z Morzem Czarnym oraz Śląsk z Rusią, które krzyżowały się właśnie we Lwowie $\mathrm{z}$ trasami biegnącymi z Czech, Węgier i Małopolski. 
W XIV w. nastąpiło przesunięcie głównego kierunku handlu z osi północpołudnie, (z tzw. drogi pruskiej, prowadzącej w kierunku Węgier), gdzie główne udziały i zyski miały takie miasta, jak: Gdańsk, Toruń, Kraków i Nowy Sącz, na kierunek osi wschód-zachód (na tzw. drogę ruską). Zmiana ta wpłynęła korzystnie na rozwój małych miast, które także mogły czerpać korzyści z handlu i z rozwoju cechów rzemieślniczych. $\mathrm{Na}$ bazie tych zmian i układów sił w sferze gospodarki handlowej rozwinęły się m.in.: Przemyśl, Jarosław, Kazimierz czy Sandomierz. Natomiast Lwów pod koniec XIV w., ze względu na lokalizację przestrzenną, stał się konkurencyjnym miastem dla Krakowa. Z północy na południe biegł więc szlak handlowy łączący Morze Bałtyckie z Węgrami. Natomiast z zachodu na wschód (przez Bramę Przemyską aż nad Morze Czarne) prowadził jeden z najstarszych europejskich szlaków handlowych - Via Regia, zwany też Wysoką lub Królewską Drogą. Według źródeł historycznych trasa ta łączyła ze sobą głównie dwa miasta - Frankfurt nad Menem i Wrocław. Od tych miast odchodziły boczne drogi. Z Frankfurtu jedno z odgałęzień prowadziło przez Kolonię, Brugię, Remis do Paryża, natomiast drugie wiodło przez Genewę i Lyon w stronę Pirenejów i Hiszpanii. Na obszarze Polski Via Regia kierowała się w stronę wschodnią, przebiegając przez Kraków, Przemyśl, Lwów do Kijowa, a także na północ, do Gdańska. Prawdopodobnie jest to jeden z najstarszych szlaków, którego początki sięgają czasów cesarstwa rzymskiego. Funkcją szlaku Via Regia była głównie wymiana handlowa, ale także polityczna i religijna (Orzechowska-Kowalska 2007).

W czasach współczesnych istnieje nawiązująca do wspomnianego powyżej szlaku, dwutorowa zelektryfikowana linia kolejowa numer 30 i międzynarodowa droga E40 oraz autostrada A4, biegnąca od dawnego przejścia granicznego do Niemiec Jędrzychowice-Ludwigsdorf koło Zgorzelca przez Wrocław, Gliwice, Katowice, Kraków, Tarnów, Rzeszów do Korczowy-Krakowca (przejścia granicznego na Ukrainę).

Również rzeka San była wykorzystywana jako szlak komunikacyjny już od czasów Kazimierza Wielkiego, największy rozkwit osiągając w XVI i XVII w. Na początku XX w. między Przemyślem a Krasiczynem kursował statek turystyczny. Od Leska spławiano nim drewno, a od Przemyśla pływały już statki rzeczne. Rzeką przewożono m.in. sól i zboże, które trafiały do Gdańska, a stamtąd do Europy Zachodniej. Transport soli pochodził z ruskich żup solnych i zaopatrywał głównie polskie ziemie wschodnie oraz Bydgoszcz i Toruń. W miastach położnych nad Sanem, takich, jak: Radymno, Jarosław, Sieniawa, Leżajsk, Ulanów, powstały porty rzeczne. Rzeka była niegdyś żeglowna na znacznie dłuższym odcinku niż obecnie, jednak późniejsze regulacje doprowadziły do jej skrócenia, a jednocześnie przyspieszenia nurtu. Skutkiem tego było znaczne spłycenie Sanu, spowodo- 
wane naniesieniem żwiru i piachu. Dzisiaj San traktowany jest jako atrakcja i wykorzystywany do turystyki wodnej (szlak wodny Błękitny San).

Jak wynika z powyższych rozważań, starożytne i średniowieczne ,autostrady” wyznaczali głównie kupcy, dlatego też lokacja miasta przy szlaku odgrywała bardzo ważną rolę. Wiele $\mathrm{z}$ wytyczonych $\mathrm{w}$ poprzednich wiekach traktów handlowych i strategicznych (wojskowych) pełni tę funkcję do dziś, o czym świadczy budowa autostrady A4 na terenie województwa podkarpackiego, która prawie w całości pokrywa się z najkrótszą drogą handlową z Krakowa przez Rzeszów do Przemyśla. Jedynie ostatni odcinek trasy, ukierunkowany do przejścia granicznego w Korczowej, zmienia jej bieg.

Rola miast, takich jak: Przemyśl, Jarosław czy Rzeszów, a przede wszystkim ich znaczenie gospodarcze i kulturowe są nierozłącznie związane z historyczną lokalizacją tych miejscowości. Ich krajobraz architektoniczny w charakterystyczny sposób odzwierciedla wielokulturową spuściznę tego regionu. W szczególności wyróżnia się tutaj Przemyśl, w którym do czasów obecnych zachowały się dwie synagogi, trzy działające cerkwie, należące do parafii prawosławnej, oraz kilkanaście klasztorów i zespołów klasztornych. Warto zaznaczyć, że lista obiektów wpisanych do rejestru zabytków, znajdujących się w Przemyślu, jest imponująca, bowiem stanowi prawie $10 \%$ ogółu wszystkich zabytków na obszarze województwa podkarpackiego. Lokacja miasta i jego położenie przygraniczne miały olbrzymi wpływ na strukturę typologiczną obiektów. Istotny jest także fakt, że od XIV w. to tutaj swoje siedziby mieli hierarchowie Cerkwi i Kościoła rzymskokatolickiego. Również współcześnie hierarcha Kościoła greckokatolickiego ma w Przemyślu swoją siedzibę, która mieści się w dawnym kościele rzymskokatolickim pod wezwaniem Najświętszego Serca Jezusowego. Także Jarosław jest miastem, w którego krajobrazie do dziś zachowały się obiekty świadczące o wielokulturowości i znaczeniu gospodarczym w poprzednich wiekach. Są to m.in. dwie synagogi, cerkiew użytkowana przez parafię greckokatolicką oraz tzw. cerkiewka (prezbiterium cerkwi cmentarnej, częściowo rozebranej w 1956 r.), liczne kościoły i zespoły klasztorne, jak również kamienice przy rynku, które w czasach świetności miasta, w okresie renesansu, wybudowali zamożni kupcy (Attavanti, Orsetti, Savioli).

\section{Podsumowanie}

Krajobraz kulturowy jest tworem żywym, który przez cały czas ulega przekształceniom. Wśród głównych czynników powodujących zmiany zachodzące w poprzednich wiekach można wymienić uwarunkowania geograficzne i historyczne. 
Na przestrzenną lokalizację obiektów wpływ miały następujące czynniki geograficzne: rzeźba terenu, lesistość oraz układ rzek. Natomiast wśród uwarunkowań historycznych jako jedne z najważniejszych można wymienić opisane powyżej zmiany granic, migracje ludności, działania zbrojne i celowe przesiedlenia mieszkańców.

W dzisiejszych czasach głównym czynnikiem wpływającym na zmieniający się krajobraz kulturowy jest industrializacja i towarzysząca temu procesowi urbanizacja. Można do tego dodać również uwarunkowania ekonomiczne, coraz więcej ludzi wyprowadza się bowiem z obszarów wiejskich do miast lub migruje za granicę w poszukiwaniu pracy i tzw. lepszego życia. Kolejne z czynników stanowią bariery kulturowo-psychologiczne, które nadal występują na tym przygranicznym terenie (m.in. stereotypy, uprzedzenia). Chociaż minęło już kilkadziesiąt lat od czasu, gdy prowadzono tam działania wojenne, w niektórych miejscowościach ludzie nadal nie chcą dbać o obiekty świadczące o obecności w nich innych kultur (m.in. o cerkwie, synagogi, kirkuty żydowskie, cmentarze ruskie). Mimo że w ciężkich powojennych czasach uczęszczali do cerkwi przekształconej w kościół rzymskokatolicki, to jednak obecnie z powodów ekonomicznych, jak i ze względu na wspomniane uprzedzenia, wolą budować nowy, często nieposiadający cech regionalnych kościół, a użytkowaną przez dziesiątki lat cerkiew pozostawić bez opieki. Trudno jest zrozumieć takie działanie proboszczów, którzy jako włodarze parafii użytkowali dany obiekt przez pięć dziesięcioleci, a następnie po prostu go opuścili. W ostatnich latach taki los spotkał m.in. cerkiew w Dachnowie, Woli Wielkiej, Leżachowie, Chotylubiu, Kramarzówce, Dobkowicach, Jaworniku Ruskim. Łącznie opuszczonych zostało 13 obiektów, co stanowi tylko, a może aż 6,5\% ich ogółu. W następstwie wskaźnik nieużytkowanych obiektów cerkiewnych na obszarze województwa podkarpackiego znacznie wzrósł i obecnie wynosi ponad 14\%. Dla porównania w okresie przed 1989 r. ogólna liczba nieużytkowanych cerkwi stanowiła jedynie $6,3 \%$ ogółu $^{6}$. W najbliższym czasie będzie ona jednak nadal wzrastać, ponieważ w kilku miejscowościach, w których znajdują się cerkwie użytkowane dotąd przez Kościół rzymskokatolicki, budowane są nowe, murowane kościoły. Warto zaznaczyć, że pomimo prowadzonych prac konserwatorskich i działań podejmowanych przez władze samorządowe, które starają się ratować dziedzictwo tego regionu, wiele $\mathrm{z}$ nieużytkowanych zabytków popada $\mathrm{w}$ ruinę. Obiekt, który nie posiada opiekuna, stałego użytkownika, mimo licznych działań zabezpieczających, będzie niszczał. Jedynie przywrócenie go do życia daje gwarancję tego, że przetrwa kolejne wieki. Przykładem takiego zaniedbania jest cer-

\footnotetext{
${ }^{6}$ Dane zebrane na podstawie badań własnych.
} 


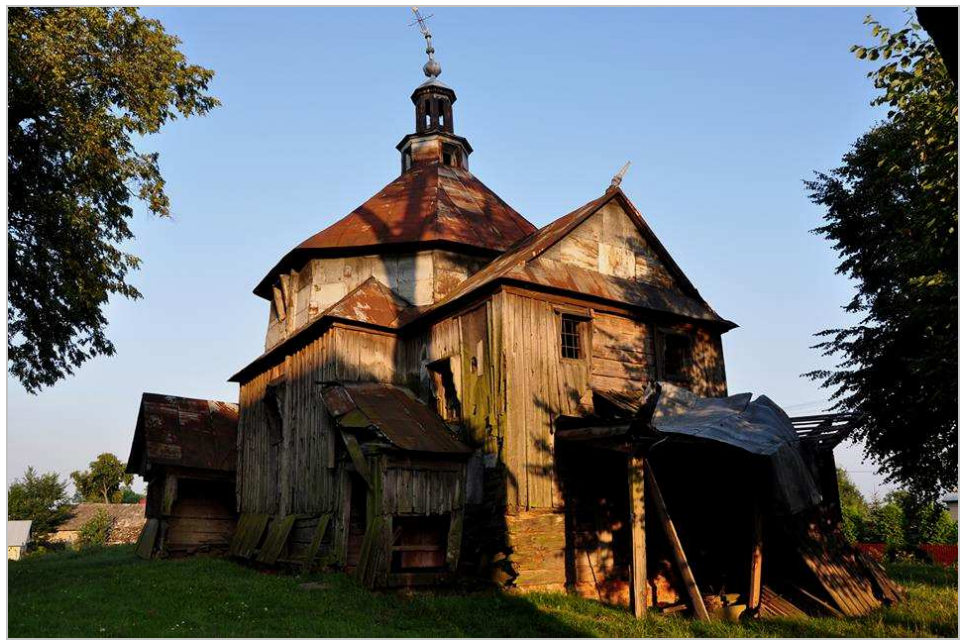

Ryc. 4. Cerkiew w Miękiszu Starym w 2010 r. Źródło: fot. M. Skulimowska

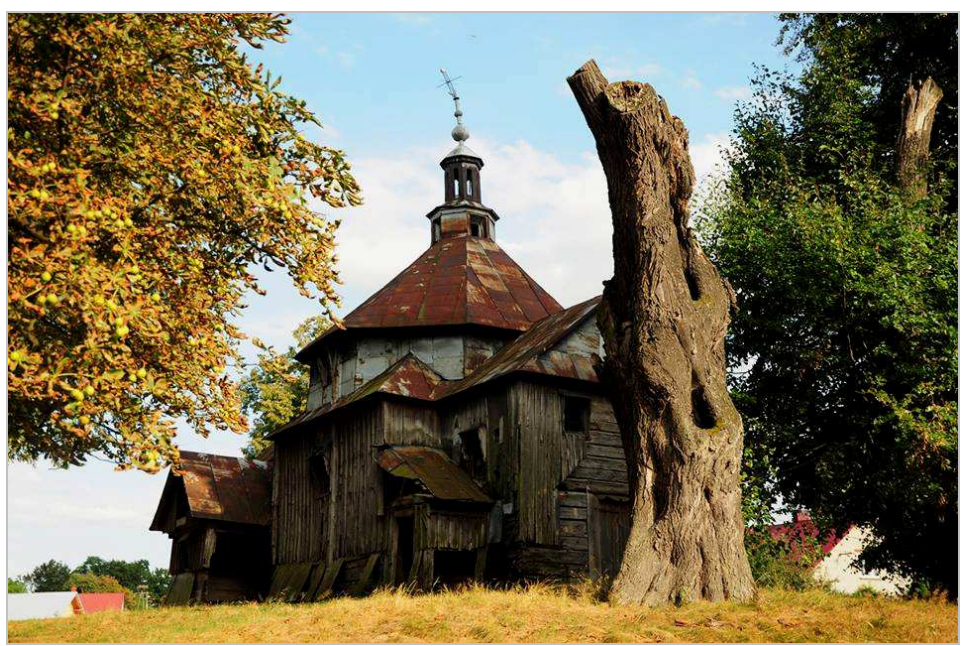

Ryc. 5. Cerkiew w Miękiszu Starym w 2013 r. Źródło: fot. M. Skulimowska

kiew w Miękiszu Starym, której najstarsza część pochodzi z 1615 r. Pomimo że budynek ten znajduje się na Szlaku Architektury Drewnianej, eksponującego najcenniejsze dziedzictwo tego regionu, dopiero w 2015 r. został wpisany do rejestru zabytków. Obiekt, od 1947 r. nieużytkowany, grozi obecnie zawaleniem, o czym informują tablice na cerkwi. W ostatnich latach zawalił się m.in. przedsionek budynku (ryc. 4 i 5). Zachowane cenne wyposażenie zostało zabezpieczone i obecnie 
przechowywane jest w Dziale Sztuki Cerkiewnej Muzeum Zamku w Łańcucie. Niestety obiekt znajduje się w rękach miejscowej parafii rzymskokatolickiej, a ta nie jest zainteresowana ratowaniem świątyni greckokatolickiej. Zarazem też nie chce się zrzec prawa do cerkwi i gruntu, na którym ona stoi. Tablica ustawiona przed obiektem informuje turystę: „,budynek jest jednym z nielicznych, w drewnianej architekturze cerkiewnej południowo-wschodniej Polski, przykładów inspirowanych murowanym barokowym budownictwem sakralnym". W związku z tym nasuwa się pytanie: dlaczego mieszkańcy nie chcą zadbać o zachowanie obiektu w krajobrazie wsi, skoro jest on jednym z nielicznych przykładów tego typu budynków?

Jako pozytywny przykład działań lokalnej społeczności warto podać Wielkie Oczy, miejscowość znajdującą się w odległości kilkunastu kilometrów od Miękisza Starego. Od XVII w. do 1935 r. Wielkie Oczy były miastem, o czym świadczy zachowany układ urbanistyczny z kwadratowym rynkiem, otoczonym kamieniczkami i drewnianymi domami, oraz XVII-wieczny dwór obronny. Pod koniec wieku XIX mieszkało tu mniej więcej 2 tys. mieszkańców, z czego ponad połowę stanowili rzymscy katolicy, a pozostałą cześć - osoby wyznania mojżeszowego i greckokatolickiego. O dawnym wspólistnieniu trzech religii świadczą zachowane obiekty sakralne tych wyznań: klasztor dominikanów z wieku XVII, murowana synagoga z 1910 r. oraz unikatowa cerkiew, wzniesiona w konstrukcji szkieletowej z muru pruskiego z 1925 r. Po kasacie klasztoru dominikanów w 1929 r. obiekty klasztorne i kościół przejęli duchowni świeccy. Eksterminacja narodu żydowskiego i wysiedlenia ludności ruskiej doprowadziły do opuszczenia tej miejscowości przez wyznawców judaizmu i grekokatolików. Pozostały tylko opuszczone świątynie, które - nieodpowiednio zagospodarowane - niszczały. Obydwa obiekty po II wojnie światowej użytkowane były przez Gminną Spółdzielnię „Samopomoc Chłopska” z Lubaczowa. Synagoga służyła kolejno jako biuro, magazyn, skład mebli i punkt skupu jaj. Natomiast cerkiew pełniła funkcję magazynu artykułów spożywczych i elektrotechnicznych. Na początku lat 90. XX w. spółdzielnię zamknięto, a obydwie świątynie przestały być użytkowane. Dzięki zaangażowaniu miejscowej ludności, samorządu lokalnego oraz potomków żydowskich mieszkańców Wielkich Oczu synagoga jako pierwsza z zabytków została wyremontowana i przywrócona do życia. Od 2011 r. pełni funkcję biblioteki oraz gminnego domu kultury (ryc. 6 i 7). Obecnie trwają również prace remontowe w cerkwi, rozpoczęte dzięki zaangażowaniu władz i mieszkańców. W odnowionej świątyni planowane jest utworzenie centrum koncertowo-wystawienniczego. 

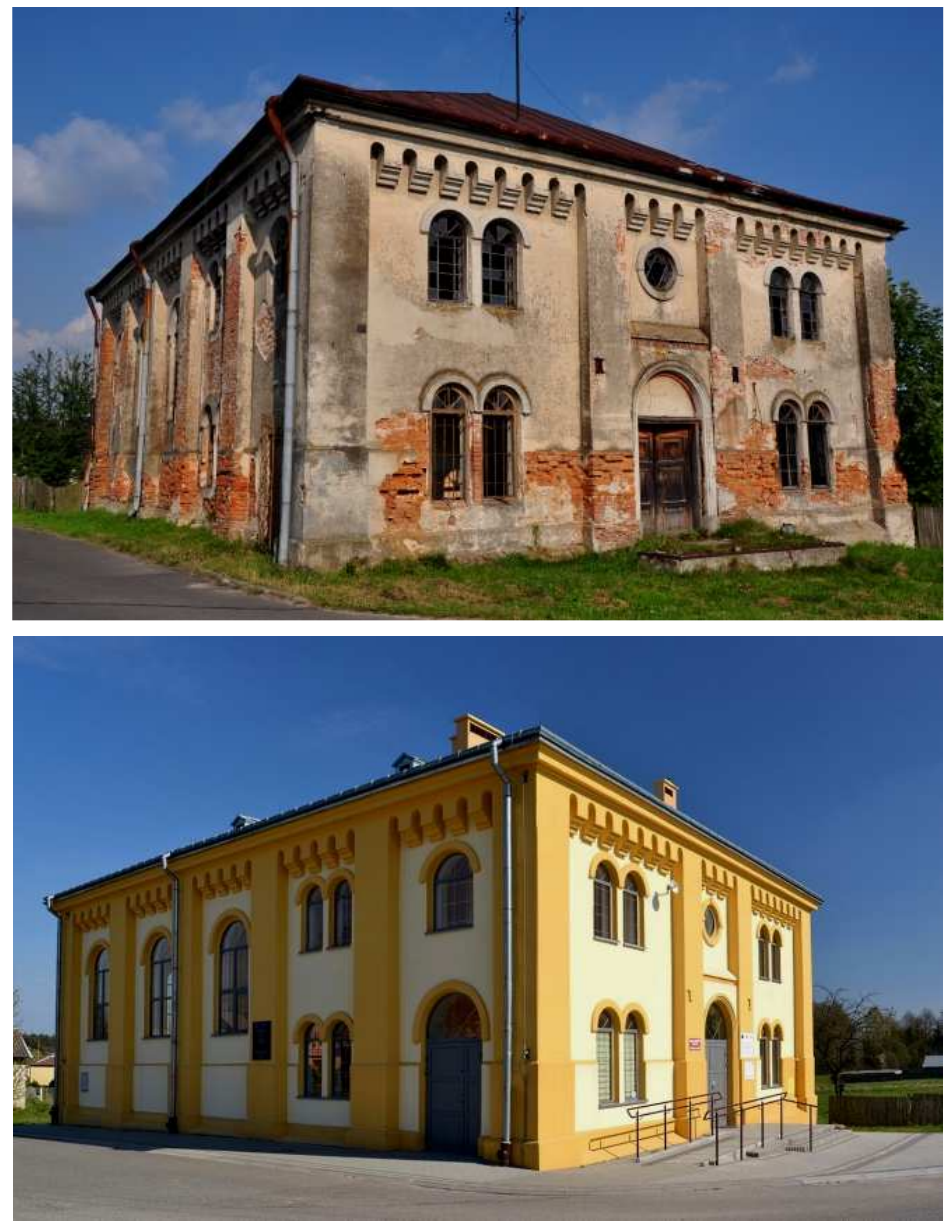

Ryc. 6 i 7. Synagoga w Wielkich Oczach w roku 2009 i 2015 Źródło: fot. M. Skulimowska

Biorąc pod uwagę tylko obszar województwa podkarpackiego, można podać zarówno wiele pozytywnych, jak i negatywnych przykładów zmian w krajobrazie kulturowym. Działania mieszkańców, władz samorządowych oraz organizacji pozarządowych wielokrotnie doprowadziły do uratowania cennych obiektów, świadczących o wielokulturowości tego regionu. Wiele zabytkowych świątyń przywrócono do dawnej świetności i znaleziono dla nich nowe funkcje. Przykładem może być m.in. cerkiew w Dubiecku, funkcjonująca obecnie jako Kresowy Dom Sztuki, którego otwarcie w 2004 r. zostało zainaugurowane wystawą pt. „Dubiecko - spotkanie trzech kultur i religii”. Uratowano nawet niektóre z obiektów znajdujących się w stanie ruiny, m.in. cerkiew w Kotowie, która po zakoń- 
czonym remoncie generalnym ma zostać zaadaptowana do potrzeb parafii rzymskokatolickiej, lub też jak podają inne źródła, stanie się miejscem odbywania się imprez kulturalnych. Przykładem użytkowania w gorszący sposób obiektu sakralnego są powojenne losy cerkwi w Kotowie - po wysiedleniu ludności ukraińskiej świątynia była magazynem na nawozy i pasze, a następnie owczarnią. Wówczas też zaczęla popadać $\mathrm{w}$ ruinę.

W ostatnich latach część obiektów została zwrócona prawowitym właścicielom, czyli parafiom greckokatolickim lub prawosławnym, jak również gminom żydowskim (np. synagoga w Rymanowie). Niestety nadal duża liczba świątyń pozostaje bez opieki. Nawet te, które przeszły generalny remont, jeśli nie pełnią żadnej funkcji użytkowej, niszczeją ponownie (np. cerkiew w Łukawcu wyremontowana w latach 90. XX w.). Cieszą wspólne działania władz samorządowych, mieszkańców i prawowitych spadkobierców świątyń, ponieważ dzięki tym przedsięwzięciom udaje się zachować wielokulturowy charakter miejscowości, takiej jak Wielkie Oczy, w której w odległości kilkuset metrów od siebie nadal znajdują się klasztor, cerkiew i synagoga...

Kto nie potrafi przyjąć całości dóbr kultury jako swojego dziedzictwa, nie jest ich godzien... Andrzej Tomaszewski

\section{Literatura}

Bańkosz R., 2010, Cerkwie Szlaku Ikon, Krosno.

Błoński J., 2008, Zaginiony świat. Historia Żydów przemyskich, Przemyśl.

Brykowski R., 1997, W sprawie architektury cerkiewnej województwa rzeszowskiego po 33 latach, [w:] Marek A. i in. (red.), Losy cerkwi w Polsce po 1944 r. Materialy sesji naukowej Stowarzyszenia Historyków Sztuki pt. ,, Tragedia polskich cerkwi” oraz artykuły zamówione przez Regionalny Ośrodek Studiów i Ochrony Środowiska Kulturowego w Rzeszowie, Rzeszów, s. 139-166.

Burczyński J. (red.), 2002, Roztocze. Środowisko przyrodnicze, Lublin.

Dobrowolska M., 1948, Dynamika krajobrazu kulturalnego, „Przegląd Geograficzny”, 21, 1, s. 151-203.

Fedan R., 2007, Charakterystyka Województwa Podkarpackiego, [w:] Kościk B. (red.), Bioenergetyka Podkarpacka, Jarosław, s. 275-332.

Harasimiuk K., Rodzoś J., 2004, Geografia Polski. W kraju ojców, Lublin.

Hettner A., 1927, Grundzüge der Landerkunde, Leipzig.

Kłos S., 2010, Krajobrazy nieistniejących wsi. Roztocze, Pogórze Przemyskie, Bieszczady, Beskid Niski, Rzeszów. 
Kondracki J., 2009, Geografia regionalna Polski, Warszawa.

Malarz R., 2003, Polska. Polskie góry, Kraków.

Marszałek E., 2010, Lasów nam przybyło, „Skarby Podkarpackie”, 3 (22), s. 26-27.

Marszałek J., 1993, Katalog grodzisk i zamczysk w Karpatach, Warszawa.

Maryański A., 1963, Współczesne ruchy migracyjne ludności w poludniowej części pogranicza polsko-radzieckiego i ich wpływ na rozmieszczenie sit wytwórczych tego obszaru, Kraków.

Michniewscy M. i A., Duda M., 2003, Cerkwie drewniane Karpat. Polska i Stowacja. Przewodnik, Pruszków.

Orłowicz M., 1921, Jarosław, jego przeszłość i zabytki. Przewodnik turystyczny, Lwów.

Orzechowska-Kowalska K., 2007, Szlak Via Regia nośnikiem wybranych wartości kulturowych, [w:] Makieła Z. (red.), Via Regia - kupiecki szlak, Jarosław.

Pisuliński J., 2008, Przesiedlenie ludności ukraińskiej/rusińskiej z Polski i Czechosłowacji na Ukrainę Sowiecka po drugiej wojnie światowej, [w:] Stolarczyk M., Kuzicki J., Grata P. (red.), Z dziejów regionów Europy Środkowo-Wschodniej w XIX $i$ XX w., Rzeszów, s. 110-124.

Potocki A., 2004, Żydzi w Podkarpackiem, Rzeszów.

Sienkiewicz W., Gryciuk G. (red.), 2008, Wysiedlenia, wypędzenia i ucieczki 1939-1959. Atlas ziem Polski, Warszawa.

Województwo podkarpackie - podregiony, powiaty, gminy, 2016, 2016, Urząd Statystyczny, Rzeszów.

\section{Dokumenty i źródła internetowe}

Dekret z 5 września 1947 r. o przejściu na własność państwa mienia pozostającego po osobach przesiedlonych do ZSRR, DzU z 1949 r., nr 59, poz. 318.

http://kalwaria.eu/strona/kalwaria-zebrzydowska-swiatowym-dziedzictwem-kultury (7.09.2017).

Uchwała nr 666 Prezydium Rządu z dnia 20 sierpnia 1955 r. w sprawie planowanej akcji usunięcia pozostałości zniszczeń wojennych w miastach i osiedlach, DzU z 1955 r., nr 92, poz. 1189.

Ustawa z 6 maja 1945 r. o majątkach opuszczonych i porzuconych, DzU z 1945 r., nr 17, poz. 97.

\section{Geographical and historical factors in shaping of cultural landscape in the area of Podkarpackie Voivodeship}

\section{Summary}

This article is to show the title connection between geographical and historical factors and the issue of shaping of cultural landscape. Therefore, both the natural and historical factors have been analysed in the area of Podkarpackie Voivodeship in comparison with its current 
borders. The area of Podkarpackie Voivodeship has undeniable cultural advantages, which have been gained over the centuries under the substantial influence of three main cultures: Polish, Ruthenian-Ukrainian and Jewish. What makes this region attractive is the multicultural character of the preserved historic buildings as well as their huge number. The main aim of the research was to determine and identify geographical and historical factors which have made an influence on the changes in the cultural landscape in the area of the current borders of Podkarpackie Voivodeship over the centuries. Historic buildings that are in the area of Podkarpackie Voivodeship, both secular and sacred, are one of the tourist attractions that appeal to visitors. But also nowadays various factors are responsible for the vanishing of some of those multicultural buildings and the landscape undergoes significant changes.

Keywords: cultural landscape, multicultural, heritage, orthodox church, synagogue.

Dr Małgorzata Skulimowska

Uniwersytet Rzeszowski

Wydział Socjologiczno-Historyczny

Instytut Historii

35-959 Rzeszów, ul. Rejtana 16

e-mail: malgosiaskul@gmail.com 